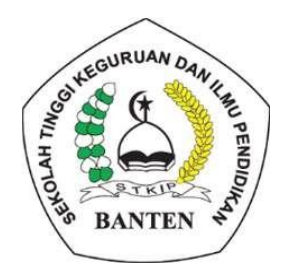

Tulip 10 (2) (2021) : 48-62

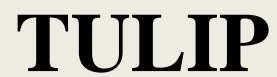

(Tulisan Ilmiah Pendidikan)

Jurnal IImiah Keguruan Dan IImu Pendidikan http://journal.stkipbanten.ac.id/index.php/tulip

\title{
PENGEMBANGAN MEDIA PEMBELAJARAN MATEMATIKA BERBASIS ADOBE FLASH PADA MATERI POLA BILANGAN SISWA KELAS VIII MTS AL- KHAIRIYAH PIPITAN KOTA SERANG
}

\author{
Fatmawati $^{1}$, Novia Ratna Sari ${ }^{2}$, Nurul Awaliyati Dewi ${ }^{3}$ \\ ${ }^{1}$ Sekolah Tinggi Keguruan dan Ilmu Pendidikan Banten \\ ${ }^{2}$ Sekolah Tinggi Keguruan dan Ilmu Pendidikan Banten \\ ${ }^{3}$ Mahasiswa Pendidikan Matematika
}

Penulis Korespondensi : ayuk.fatma1706@gmail.com ${ }^{1}$, noviars.21@gmail.com² nurulawaliatidewi@gmail.com ${ }^{3}$

Artikel :

Pengembangan Media Pembelajan Matematika Berbasis Adobe Flash

Penerima: Juli 2021

Diterima: Agustus 2021

Dipublikasikan: September 2021

\begin{abstract}
The purpose of this study was to determine the feasibility of Adobe Flash-based mathematics learning media on the number pattern material for class VIII MTs Al-KhairiyahPipitan students. This type of research is development research or in English Research and Development refers according to Sugiono which consists of ten steps but the researcher limits it to only six steps that are tailored to the needs of the researcher, namely potential and problems, data collection, product design, design validation, design revision. and product trials. The data collection technique used by the researcher was a questionnaire which was presented as a percentage.The final result of this research has been a product trial. It is evident from the adobe flash-based mathematics learning media product that was tested on VIII E grade students and mathematics teachers at MTs Al-KhairiyahPipitan. With the results of the student response questionnaire of $85 \%$ and the results of the teacher's response questionnaire of $84.5 \%$ with the "Very Eligible" criteria, it means that the development of adobe flash-based mathematics learning media on number pattern material is feasible to use. So it can be concluded that the adobe flash-based mathematics learning media is feasible as mathematics learning media in the number pattern material for class VIII students of MTs Al-KhairiyahPipitan.
\end{abstract}

Keywords : Mathematics Learning Media, Adobe Flash, Number Pattern

\begin{abstract}
ABSTRAK
Tujuan penelitian ini untuk mengetahui kelayakan media pembelajaran matematika berbasis Adobe Flash pada materi pola bilangan siswa kelas VIII MTs Al- Khairiyah Pipitan. Jenis penelitian ini adalah penelitian pengembangan atau dalam bahasa inggris Research and Development mengacu menurut Sugiono yang terdiri dari sepuluh langkah namun peneliti membatasi hanya sampai enam langkah yang disesuaikan dengan kebutuhan peneliti, yakni potensi dan masalah, pengumpulan data, desain produk, validasi desain, revisi desain, dan uji coba produk. Teknik pengumpulan data peneliti menggunakan angket kuesioner yang disajikan dalam persentase. Hasil akhir penelitian initelah dilakukan ujicoba produk. Terbukti dari produk media pembelajaran matematika berbasis adobe flash yang diujicobakan kepada Siswa kelas VIII E dan Guru matematika di MTs Al-Khairiyah Pipitan. Dengan hasil angket respon Siswa sebesar 85\% dan hasil angket respon Guru sebesar 84,5\% dengan kriteria "Sangat Layak" artinya pengembangan media pembelajaran matematika berbasis adobe flash pada materi pola bilangan layak digunakan. Sehingga dapat disimpulkan media pembelajaran matematika berbasis adobe flash layak sebagai media pembelajaran matematika pada materi pola bilangan siswa kelas VIII MTs Al-Khairiyah Pipitan.
\end{abstract}

Kata Kunci : Media Pembelajaran Matematika, Adobe Flash, Pola Bilangan 
2 |Fatmawati, Novia Ratna Sari, Nurul Awaliyati Dewi, Pengembangan Media Pembelajaran Berbasis Adobe Flash Pada Materi Pola Bilangan

\section{PENDAHULUAN}

Perkembangan teknologi informasi beberapa tahun belakangan ini berkembang dengan kecepatan yang sangat tinggi, sehingga dengan perkembangan ini telah mengubah paradigma masyarakat dalam mencari dan mendapatkan informasi yang tidak lagi terbatas pada informasi surat kabar, audio visual, dan elektronik, tetapi juga sumber informasi lainnya yaitu melalui jaringan internet. Salah satu bidang yang mendapatkan dampak cukup banyak terhadap perkembangan teknologi yaitu bidang pendidikan. Dimana pada dasarnya pendidikan merupakan proses komunikasi dan informasi dari pendidik kepada peserta didik. Para guru dituntut untuk menggunakan alat-alat yang dapat disediakan disekolah dan tidak menutup kemungkinan alat-alat tersebut sesuai dengan perkembangan dan tuntutan zaman.

Guru sekurang-kurangnya dapat menggunakan alat yang murah dan efesien yang meskipun sederhana dan bersahaja, tetapi merupakan keharusan dalam upaya mencapai tujuan pengajaran yang diharapkan. Disamping mampu menggunakan alat-alat yang tersedia, guru juga dituntut untuk dapat mengembangkan keterampilan membuat media pembelajaran yang akan digunakannya apabila media tersebut belum tersedia. Media adalah bagian yang tidak dapat dipisahkan dariproses Media memiliki konotasi yang terlalu luas dan kompleks. Kesulitan mendefinisikan media sangat terasa apalagi dikaitkan dengan beberapa istilah lain seperti sistem penyajian dan teknologi pembelajaran.

Media juga dipandang sebagai bentuk-bentuk komunikasi massa yang melibatkan sistem simbol dan peralatan produksi dan distribusi. Media mengacu pada segala sesuatu yang berfungsi untuk membawa dan menyampaikan informasi antara sumber dan penerima informasi. Misalnya video, televisi, bahan cetak, komputer, dan instruktur, dianggap sebagai media karena sebagai media karena berfungsimembawa pesan untuk tujuan pembelajaran. Tujuan media adalah untuk memfasilitasi berlangsungnya komunikasi Gagne dan Bringgs juga mengatakan bahwa sebenarnya penyebutan media pembelajaran tidak memiliki makna yang standar.

Berdasarkan wawancara pada Juni 2021 dengan guru Matematika MTs AlKhairiyah Pipitan, Ibu Nurul Awaliyah, S.Pd. Diketahui bahwa belum pernah digunakannya media Adobe Flash yang dapat membantu guru dalam menyampaikan materi matematika kepada peserta didik sehingga menjadi hambatan dalam pelaksanaan proses belajar mengajar. Guru masih menggunakan metode ceramah atau konvensional ketika menyampaikan materi, menyebabkan peserta didik cenderung pasif dalam Proses pembelajaran. Kurangnya guru dalam menggunakan media pembelajaran menjadikan peserta didik bosan. Teknologi komputer belum dimanfaatkan dengan efektif untuk pembelajaran Matematika pada materi pola bilangan, sehingga menyebabkan turunnya motivasi dan minat belajar peserta didik.

dalam $\begin{gathered}\text { Terbatasnya pengetahuan guru } \\ \text { mengembangkan media }\end{gathered}$ pembelajaran berbasis audio visual sebagai media guru untuk menyampaikan materi pelajaran. Dari permasalahan tersebut peneliti tertarik untuk melakukan penelitian pada materi pola bilangan yang dikemas menggunakan media pembelajaran berbasis adobe flash karena menyesuaikan dengan sub bab pada kelas VIII semester ganjil tingkat sekolah menengah dan waktu penelitian saat ini.

Profesionalisme guru tidak cukup hanya dengan membelajarkan siswa, tetapi juga mengolah informasi dan lingkungan untuk memfasilitasi kegiatan belajar, salah satunya dengan memperkaya sumber dan media pembelajaran. Penjelasan tersebut sesuai dengan PP nomor 74 tahun 2008 yang menyatakan guru sekurang- 
kurangnya memiliki kompetensi menggunakan teknologi komunikasi dan informasi secara fungsional. Semakin sadarnya orang akan pentingnya media yang membantu pembelajaran sudah mulai dirasakan. Pengelolaan alat bantu pembelajaran yang sangat dibutuhkan. Metamorfosis dari perpustakaan yang menekankan pada penyediaan media cetak, menjadi penyediaan-permintaan dan pemberian layanan secara luas. Selain itu, dengan semakin meluasnya kemajuan dibidang komunikasi dan teknologi, serta diketemukannya dinamika proses belajar, maka pelaksanaan kegiatan pendidikan dan pengajaran semakin menuntut dan memperoleh media pendidikan yang bervariasi secara luas.

Pembelajaran berbasis teknologi informasi dan komunikasi adalah proses pembelajaran yang menggunakan perangkat komputer dan internet sebagai salah satu alat untuk menyampaikan materi pembelajaran yang lebih interaktif, inovatif, dan menyenangkan. Salah satu media pembelajaran yang mengemas konsep pembelajaran interaktif, inovatif, dan menyenangkan yaitu multimedia berbasis adobe flash. Adobe flash merupakan software yang dapat digunakan untuk membantu animasi, game, presentasi, web, animasi pembelajaran dan film.Adobe flashprofessional CS6 merupakan software populer yang banyak dimanfaatkan oleh kalangan guru atau pengajar untuk membuat media pembelajaran dalam dunia pendidikan, serta bagi profesional untuk pembuatan presentasi, animasi game, dan lain-lain.Menurut akbar, adobe flashCS6 merupakan salah satu aplikasi pembuatan media pembelajaran interaktif yang mudah dan dapat digunakan oleh semua orang. Kelebihan dari adobe flash CS6 yaitu memiliki fitur yang banyak sehingga mampu menghubungkan gambar, suara, dan animasi secara bersamaan.

Berdasarkan definisi yang telah dijabarkan, yang dimaksud dengan media pembelajaran adalah semua bentuk peralatan fisik yang didesain secara terencana untuk menyampaikan informasi dan membangun interaksi. Bahwa proses pendidikan tidak harus dilaksanakan secara konvensional, namun guru dapat mencari dan mempergunakan alternatif atau sumber belajar lain untuk menjadikan proses belajar mengajar yang awalnya abstrak dan sulit dipahami menjadi sebuah materi yang menarik serta mudah dipahami.Uraian tersebut mendasari penelitian ini dilakukan dalam rangka mengembangkan sebuah media pembelajaran menggunkan aplikasi Adobe Flash. Pengembangan media pembelajaran dilakukan pada materi Pola Bilangan agar dapat disampaikan dengan menarik, sehingga pembelajaran tidak monoton dan membosankan dan mampu meningkatkan motivasi belajar matematika peserta didik.

Sesuai permasalahan diatas, rumusan masalah dalam penelitian ini adalah "Bagaimana kelayakan media pembelajaran matematika berbasis Adobe Flash sebagai media pembelajaran untuk materi pola bilangan siswa kelas VIII MTs Al-Khairiyah Pipitan?"

Adapun tujuan dari penelitian ini adalah "untuk mengetahui kelayakan media pembelajaran matematika berbasis Adobe Flash pada materi pola bilangan siswa kelas VIII MTs Al- Khairiyah Pipitan.

\section{Secara Teoritis}

Penelitian ini dapat memberikan
informasi mengenai $r$ bentuk
Pengembangan Media Pembelajaran
Matematika Berbasis Adobe Flash pada
materi Pola Bilangan.

2. Secara Praktis

a. Bagi Peneliti, Penelitian ini sangat bermanfaat sebagai buah karya ilmiah dan sebagai syarat untuk meraih gelar sarjana kependidikan di Sekolah Tinggi Keguruan dan Ilmu Pendidikan Banten.

b. Bagi Siswa, Penelitian ini diharapkan dapat menciptakan pembelajaran matematika yang menyenangkan dan memacu motivasi dan minat belajar siswa. 
4|Fatmawati, Novia Ratna Sari, Nurul Awaliyati Dewi, Pengembangan Media Pembelajaran Matematika Berbasis Adobe Flash Pada Materi Pola Bilangan

c. Bagi Guru, Diharapkan dengan adanya hasil penelitian ini dapat menjadi masukkan bagi pihak sekolah dan upaya sosialisasi penggunaan media pembelajaran menggunkan Adobe Flash dalam pelajaran Matematika.

d. Bagi Sekolah, Memberikan bantuan pemikiran dan evaluasi hubungan antara lingkungan keluarga, lingkungan sekolah, dan lingkungan masyarakat secara bersama-sama. Dengan kemampuan belajar siswa kelas VIII MTs Al-KhairiyahPipitan, agar pelaksanaan selanjutnya lebih baik lagi.

\section{LANDASAN TEORI}

\section{Pengembangan}

Salah satu kawasan (domain) yang banyak mendapat perhatian dalam kajian teknologi pendidikan adalah bidang pengembangan. Akar domain ini diarahkan pada produksi media mulai dari media cetak, audiovisual, sampai pada teknologi komputer dan integrasi teknologi yang dikendalikan oleh komputer. Ketika orang menyebut pengembangan pikiran kita tertuju pada pada tiga hal. Pertama, produk pengembangannya walaupun yang dihasilkan itu merupakan penyempurnaan dari produk yang sudah ada sebelumnya ataupun produk baru yan dihasilkan melalui pengembangan. Kedua, istilah pengembangan merujuk pada prosedur, tahapan, atau hierarki sistematik dan sistematis yang dilakukan untuk menghasilkan sesuatu. Ketiga, pengembangan selalu berhubungan dengan model, baik model yang berorientasi ruang kelas (classroom oriented model) seperti pengembangan bahan ajar, strategi, media, metode, dan evaluasi pembelajaran, model yang berorientasi produk (product oriented model) seperti media dan teknologi, maupun model yang berorientasi sistem (system oriented model) seperti pembelajaran jarak jauh, pembukaan program atau jurusan dan semacamnya.

Menurut Revood dalam Yaumi mengatakan bahwa, pengembangan adalah produksi aktual dari konten dan bahan belajar berdasarkan fase desain. Fase desain maksudnya adalah tahapan-tahapan sistematis yang dimulai dengan menganalisis kebutuhan (konteks, karakteristik peserta didik, dan kompetensi), merumuskan tujuan, mengembangkan instrumen penilaian, strategi (aktivitas, metode dan media), bahan dan evaluasi pembelajaran.

\section{Media Pembelajaran}

a. Pengertian Media Pembelajaran

Kata media berasal dari bahasa Latin medius yang secara harfiah berarti tengah, perantara, atau pengantar. Secara lebih khusus, pengertian media dalam proses belajar mengajar atau elektronik untuk menangkap, memproses, dan menyusun kembali inormasi visual atau verbal.

AECT (Association of Education and Communication Technology) memberi batasan tentang media sebagai segala bentuk dan saluran yang digunakan untuk menyampaikan pesan atau informasi. Disamping sebagai sistem penyampai atau pengantar, media yang sering diganti dengan kata mediator. Dengan istilah mediator, media menunjukkan fungsi atau perannya yaitu mengatur hubungan yang efektif antara dua pihak utama dalam proses belajar, yaitu peserta didik dan isi pelajaran.

Ringkasnya media adalah alat yang menyampaikan atau mengantarkan pesan-pesan pembelajaran. Pembuatan aplikasi multimedia menggunakan software Adobe Flash (dahulu bernama 
Macromedia Flash) software ini merupakan salah satu perangkat lunak komputer yang merupakan produk unggulan Adobe Sistem. Adobe Flash digunakan untuk membuat gambar vector maupun animasi gambar. Penggunaan multimedia sebagai alat bantu belajar merupakan solusi dari permasalahan ini

b. Fungsi Media Pembelajaran

Fungsi media diantaranya yaitu :

1) Fungsi afektif : Media visual dapat terlihat dari tingkat kenikmatan siswa ketika siswa (atau membaca) teks yang bergambar.

2) Fungsi kognitif : Media visual terlihat dari temuan-temuan penelitian yang menggungkapkan bahwa lambang visual atau gambar memperlancar pencapaian tujuan untuk memahami dan mengingat informasi atau pesan yang terkandung dalam gambar.

3) Fungsi Kompensatoris : Media pembelajaran terlihat dari hasil penelitian bahwa media visual yang memberikan konteks untuk memahami teks membantu siswa yang lemah dalam membaca untuk mengorganisasikan informasi dalam teks dan mengingatnya kembali.

c. Manfaat Media Pembelajaran

Manfaat media pembelajaran yaitu :

1) Meningkatkan rasa saling pengertian dan simpati dalam kelas

2) Menunjukkan perubahan signifikan tingkah laku siswa

3) Menunjukkan hubungan antara mata pelajaran dan kebutuhan dan minat siswa dengan meningkatnya motivasi belajar siswa.

4) Membawa kesegaran dan variasi bagi pengalaman belajar siswa.

5) Membuat hasil belajar lebih bermakna bagi berbagai kemampuan siswa. Manfaat media yang dipaparkan oleh Dale tersebut dapat disimpulkan bahwa media pembelajaran memberikan manfaat asalkan guru aktif berperan dalam proses pembelajaran.

\section{d. Jenis-jenis Media}

1) Media berbasis manusia

Media berbasis manusia merupakan media yang digunakan untuk mengirim dan mengkomunikasikan peran atau informasi.

2) Media berbasis cetakan

Media pembelajaran berbasis cetakan yang paling umum dikenal adalah buku tesk, buku penuntun, buku kerja atau latihan, jurnal, majalah, dan lembar lepas.

3) Media berbasis visual

Media berbasis visusal (image) dalam hal ini memegang peranyang sangat penting dalam proses belajar. Media visual dapat memperlancar pemahaman dan memperkuat ingatan. Visual dapat pula menumbuhkan minat peserta didik dan dapat memberikan hubungan antara isi materi pelajaran dengan dunia nyata.

4) Media berbasis audio visual Media yang menggabungkan pungguran suara memerlukan pekerjaan tambahan untuk memproduksinya. Salah satu pekerjaan penting yang diperlukan dalam media audiovisual adalah penulisan naskah dan story board yang memerlukan persiapan yang banyak, rancangan dan penelitian.

5) Media berbasis komputer

Komputer memilih fungsi yang berbeda-beda dalam bidang 
6 |Fatmawati, Novia Ratna Sari, Nurul Awaliyati Dewi, Pengembangan Media

Pembelajaran Matematika Berbasis Adobe Flash Pada Materi Pola Bilangan

pendidikan dan latihan komputer berperan sebagai manajer dalam proses pembelajaran yang dikenal dengan nama Computer Managed Instruction (CMI). Modus ini dikenal sebagai Computer Assisted Instruction (CAI). CAI mendukung pembelajaran dan pelatihan, akan tetapi ia bukanlah penyampai utama materi pelajaran.

\section{Langkah-langkah Pengembangan}

Secara garis besar kegiatan pengembangan media pembelajaran terdiri atas tiga langkah yang harus dilalui, yaitu kegiatan perencanaan,produksi dan penilaian. Adapun urutan langkah-langkah yang harus diambil dalam pengembangan media ini adalah sebagai berikut :

1) Menganalisis kebutuhan dan karakteristik peserta didik.

2) Merumuskan tujuan instruksional dengan operasional dan khas.

3) Merumuskan butir-butir materi secara terperinci yang mendukung tercapainya tujuan.

4) Mengadakan test dan revisi.

\section{Adobe Flash}

Menurut Akbar dalam jurnal Sofiyatul Hidayah Adobe Flash CS6 merupakan salah satu aplikasi pembuatan media pembelajaran interakif yang mudah dan dapat digunakan oleh semua orang. Kelebihan Adobe Flash CS6 yaitu memiliki fitur yang banyak sehingga mampu sehingga mampu menghubungkan gambar, suara dan animasi secara bersamaan.

\section{Adobe flash merupakan software}

yang dapat digunakan untuk membuat animasi, game, presentasi, web, animasi pembelajaran dan film. Animasi yang dihasilkan oleh adobe flash berupa animasi file movie. Movie yang dihasilkan berupa grafik ataupun teks. Selain itu juga, adobe flash memiliki kemampuan untuk mengimpor file suara, video, dan gambar dari aplikasi lain.

Dari beberapa penjelasan diatas, bahwa dengan adanya pengembangan media pembelajaran berbasis Adobe Flash dapat memudahkan penyampaian materi khususnya pada materi matematika yang dianggap membosankan oleh siswa. Karena software Adobe Flash memiliki berbagai menu yang bisa menanpilkan gambar, suara dan animasi.

\section{Hakikat Matematika}

Karakteristik lainnya adalah matematika sebagai bahasa yang memiliki beberapa kesamaan dengan bahasa lainnya antara lain, mereka memiliki aturan dan istilah tertentu. Perbedaan matematika dengan bahasa lainnya diantaranya, adalah matematika merupakan bahasa yang khusus dengan sifat-sifatnya yang unik. Sebagai bahasa yang sifatnya unik, matematia mempunyai beberapa nama, misalnya matematika sebagai extention language atau matematika sebagai formal language atau sebagai symbolic language.

Dapat disimpulkan karakteristik matematika lainnya adalah sifatnya yang menekanan pada proses deduktif yang memerlukan penalaran logis dan aksiomatik, yang diawali dengan proses induktif yang meliputi penyusunan konjektur, model matematika, analogi dan generalisasi, 
melalui pengamatan terhadap sejumlah data.

\section{Pola Bilangan}

Pola adalah barisan bilangan yang suku-sukunya dapat diprediksi mendefinisikan pola bilangan sebagai barisan bilangan dimana ada aturanyang terdefinisi dengan baik untuk menghitung setiap bilangan dari bilangan sebelumnya atau dari posisi barisannya. Pola bilangan atau objek yang berubah dari satu suku kesuku berikutnya dengan cara yang dapat diprediksi. Definisi pola bilangan matematika adalah susunan dari beberapa angka yang dapat membentuk pola tertentu. Pola bilangan juga bisa diartikan sebagai suatu susunan yang memiliki bentuk teratur atau suatu bilangan yang tersusun dari beberapa bilangan lain yang membentuk suatu pola. Dari beberapa pola tersebut maka akan membentuk sebuah gambar yang kemudian bisa dihitung.

Jenis-jenis pola bilangan

Berikut ini merupakan beberapa susunan bilangan yang memiliki pola tertentu yang berhubungan dengan bilangan asli :

1) Pola bilangan ganjil

2) Pola bilangan genap

3) Pola bilangan persegi panjang

4) Pola bilangan persegi

5) Pola bilangan segitiga

6) Pola bilangan pascal

7) Pola bilangan fibonacci

Berdasarkan pendapat diatas dapat diketahui bahwa materi pola bilangan adalah salah satu materi yang dipelajari oleh siswa kelas VIII tingkat SMP/MTs sederajat. Pola bilangan matematika yaitu susunan dari beberapa angka yang membentuk pola bilangan.

\section{METODOLOGI PENELITIAN}

Menurut Sugiyono dalam bukunya, metode penelitian dan pengembangan dalam bahasa Inggris yaitu Research and Development adalah metode penelitian yang digunakan untuk menghasilkan produk tertentu dan menguji keefektifan produk tersebut. Penelitian dan pengembangan merupakan suatu proses atau langkah-langkah untuk mengembangkan suatu produk baru atau menyempurnakan produk yang telah ada dan dapat dipertanggungjawabkan.

Produk tersebut dapat berupa perangkat keras ataupun perangkat lunak. Perangkat keras misalnya buku, modul, alat bantu pembelajaran dikelas. Perangkat lunak meliputi program komputer pengolahan data, pembelajaran dikelas, perpustakaan, model-model pendidikan pembelajaran, pelatihan, bimbingan, evaluasi, manajemen dan lain-lain. Langkah-langkah yang harus di ikuti untuk menghasilkan produk meliputi tahap potensi dan masalah, pengumpulan data, desain produk, validasi desain, revisi desain produk, uji coba produk, revisi produk, uji coba pemakaian, revisi produk, dan produksi masal. Jadi penelitian pengembangan harus memenuhi beberapa langkah agar produk tersebut layak digunakan.

Subjek penelitian yaitu dilakukan pada Siswa Kelas VIII E MTs Al-Khairiyah Pipitan dengan jumlah 30 peserta didik, karena pembelajaran Matematika pada materi Pola Bilangan masih dilakukan secara konvensional.

Lokasi Penelitian bertempat di MTs Al-Khairiyah Pipitan, yang beralamat di Jl. Raya Ciruas - Walantaka No. 2, Pipitan, Kec. Walantaka Kota Serang, Banten.

\section{Langkah-Langkah Penelitian dan Pengembangan}

Pada penelitian pengembangan ini mengacu pada prosedur penelitian 
$8 \mid$ Fatmawati, Novia Ratna Sari, Nurul Awaliyati Dewi, Pengembangan Media Pembelajaran Matematika Berbasis Adobe Flash Pada Materi Pola Bilangan

pengembangan menurut Sugiyono yang disesuaikan dengan kebutuhan peneliti. Prosedur penelitian yang dilakukan oleh peneliti dapat dapat dilihat dibawah ini

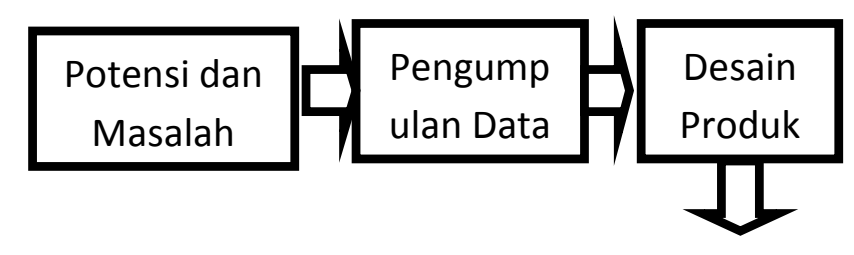

HASIL DAN PEMBAHASAN Hasil Penelitian

Bab ini menjelaskan mengenai proses dan hasil produk media pembelajaran matematika yang telah dikembangkan. Dalam hal ini, produk yang dikembangkan berupa media pembelajaran matematika berbasis adobe flash pada materi pola bilangan. Berdasarkan penelitian dan pengembangan yang dilakukan, diperoleh hasil penelitian berupa tahapan-tahapan sebagai berikut :

\section{Gambar 3.1 Prosedur Penelitian Pengembangan}

\section{Subjek Penelitian}

Subjek Validasi

$\begin{array}{ll}\text { Ahli Media } & \text { : Guru/Dosen yang paham } \\ & \text { tentang media } \\ \text { Ahli Materi } & \text { : Guru Matematika yang } \\ & \text { sudah berpengalaman } \\ & \text { mengajar matematika dan } \\ & \text { pendidikan S-1 Matematik }\end{array}$

Teknik pengumpulan data yang digunakan pada penelitian ini adalah dengan menggunakan angket atau kuesioner.Bentuk dari kuesionernya adalah check list. Responden tinggal membubuhkan tanda ceklis $(\sqrt{ })$ pada kolom yang sesuai. Dengan jumlah pernyataan 15 butir.

Instrumen pengumpulan data yang digunakan yaitu instrumen validasi ahli media, instrumen validasi ahli materi, instrumen penilaian siswa, dan instrumen penilaian guru matematika.

Dapat diketahui ada lima kriteria yang digunakan sesuai dengan analisis skala likert terdiri dari kriteria sangat layak, layak, cukup layak, tidak layak dan sangat tidak layak.Analisis perhitungannya adalah :Jumlah skor kriterium

$(\mathrm{N})=\frac{\text { Jumlah skor validasi } \text { keseluruhan }}{\text { Jumlah pernyataan } x \text { jumlah }} \times 100$

(C) 2021, Tulip, Jurnal Tulisan IImiah Pendidikan. STKIPB e-ISSN: 2807-4114

\section{a. Potensi dan Masalah}

Potensi dan masalah diperoleh dari hasil wawancara pra penelitian dengan guru matematika di MTs Al-Akhairiyah pipitan.

\section{b. Pengumpulan Informasi}

Pengumpulan informasi yang dilakukan dengan membagikan angket atau kuesioner kepada siswa kelas VIII dan guru matematika di MTs Al-Khairiyah Pipitan.

\section{c. Desain Produk}

Tahap selanjutnya adalah merancang dan mengembangkan media pembelajaran berbasis adobe flash kemudian didesain sedemikian rupa dan disesuikan dengan materi matematika disemesterini agar layak dalam penggunaan pada pembelajaran matematika. Di bawah ini adalah hasil desain media pembelajaran adobe flash.

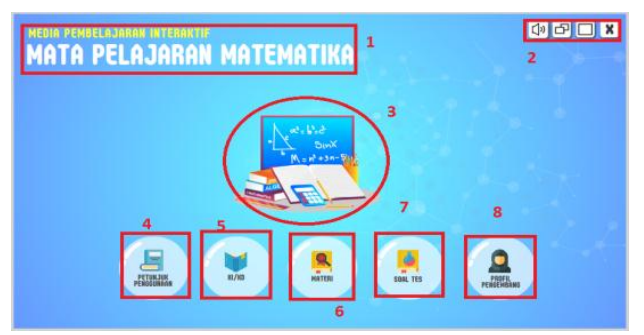

\section{Gambar 4.1 Tampilan Media Pembelajaran Matematika Berbasis Adobe Flash}

Gambar 4.1 diatas menunjukkan tampilan awal dari media pembelajaran matematika berbasis adobe flash pada 
materi pola bilangan siswa kelas VIII. Adapun penjelasan dari gambar tampilan diatas adalah : (1) Judul media pembelajaran, (2) Empat tombol itu terdiri dari pertama tombol mute untuk menonaktifkan dan menghidupkan volume, kedua tombol minimaze berfungsi untuk memperkecil layar tampilan, ketiga tombol maximaze untuk memperbesar layar tampilan, keempat tompol $\mathrm{x}$ atau close untuk menutup tampilan, (3) Gambar papan tulis dan buku menunjukan ciri pembelajaran matematika, (4) Menu petunjuk penggunaan, (5) Menu penjelasan $\mathrm{KI} / \mathrm{KD}$, (6) Menu penjelasan materi, (7) Menu soal test interaktif, (8) Menu profil pengembang.

Dalam pengembangan media pembelajaran matematika berbasis adobe flash ini fokus pada pengembangan menu materi dan latihan soal. Perolehan nilai dapat dilihat jika sudah menyelesaikan soal tersebut. Untuk lebih jelasnya, gambar dibawah ini akan menjelaskan bagian menu materi dan menu soal test.

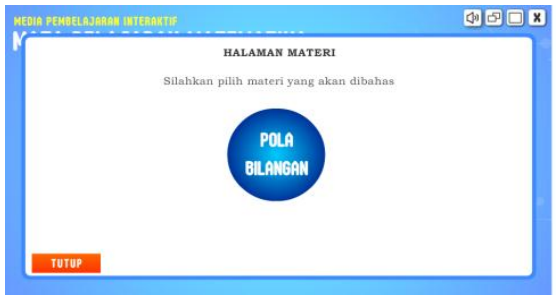

\section{Gambar 4.2 Tampilan Halaman Materi Pola Bilangan}

Gambar 4.2 diatas adalah tampilan pertama menu materi berupa tombol dengan nama pola bilangan, jika mengklik tombol tersebut maka akan muncul kumpulan materi tentang pola bilangan seperti dibawah ini.

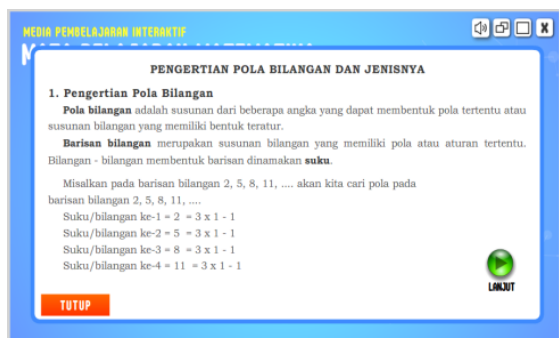

\section{Gambar 4.3 Tampilan Menu Materi Pengertian Pola Bilangan}

(C) 2021, Tulip, Jurnal Tulisan IImiah Pendidikan. STKIPB e-ISSN: 2807-4114
Gambar 4.3 diatas merupakan tampilan pertama dari isi menu materi tentang pola bilangan, berupa penjelasan pengertian pola bilangan dan barisan bilangan. Adapan tombol" tutup" yaitu untuk menutup menu materi, dan tombol "tanda panah" kekanan yang berarti untuk lanjut ke menu materi berikutnya maka akan muncul menu seperti dibawah ini.

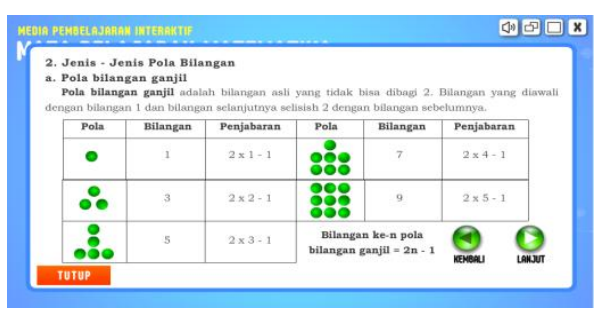

\section{Gambar 4.4 Tampilan Menu Materi Pola Bilangan Ganjil}

Tampilan gambar yang selanjutnya adalah tampilan menu yang menjelaskan jenis-jenis pola bilangan. Gambar 4.4 tersebut menjelaskan jenis pola bilangan ganjil beserta rumusnya. Dan tombol "panah kekanan" pada menu untuk melanjutkan menu berikutnya, sedangkan tombol "panah kekiri" untuk kembali ke menu sebelumnya.

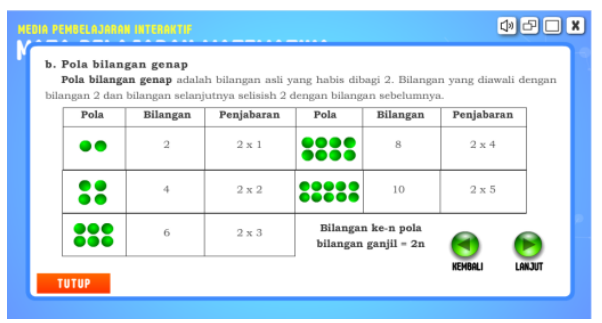

\section{Gambar 4.5 Tampilan Menu Materi Pola Bilangan Genap}

Pada gambar 4.5 diatas kita dapat mengetahui bahwa jenis pola bilangan berikutnya adalah pola bilangan genap. Digambar tersebut terdapat rumus dan peniabaran dari rumus pola bilangan genap.

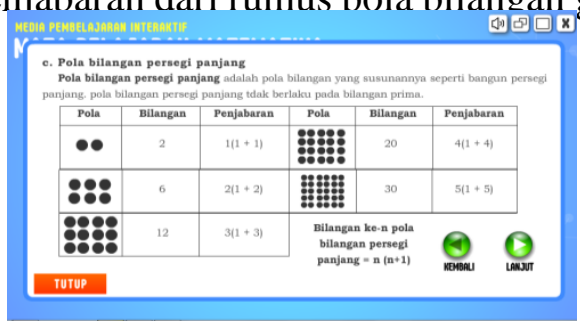

\section{Gambar 4.6 Tampilan Menu Materi Pola Bilangan Persegi Panjang}


10 Fatmawati, Novia Ratna Sari, Nurul Awaliyati Dewi, Pengembangan Media Pembelajaran Matematika Berbasis Adobe Flash Pada Materi Pola Bilangan

Gambar diatas menjelaskan pola bilangan berikutnya yaitu pola bilangan persegi panjang lengkap dengan rumusnya.

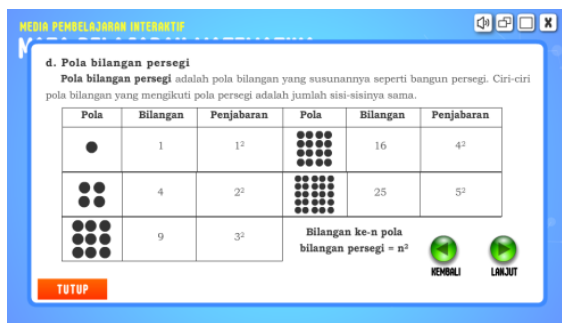

\section{Gambar 4.7 Tampilan Menu Materi Pola Bilangan Persegi}

Pada gambar 4.7 diatas yaitu menjelaskan menu materi pola bilangan yaitu jenis pola bilangan persegi beserta dengan rumusnya.

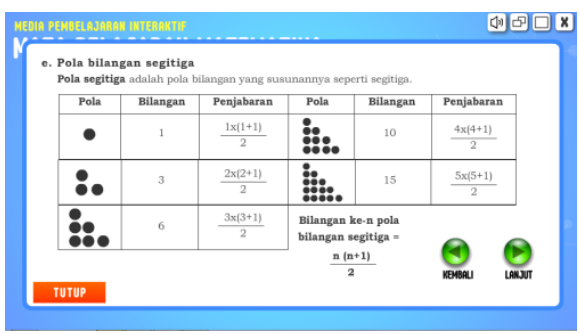

Gambar 4.8 Tampilan Menu Materi Pola Bilangan Segitiga

Gambar diatas adalah tampilan menu materi pola bilangan jenis pola bilangan segitiga dengan rumus dan penjelasan rumusnya. Ditabel tersebut ada pula gambar seperti segitiga yang membedakan dengan pola bilangan lainnya. Adapun jenis pola bilangan berikutnya adalah pola bilangan segitiga pascal seperti di bawah ini.

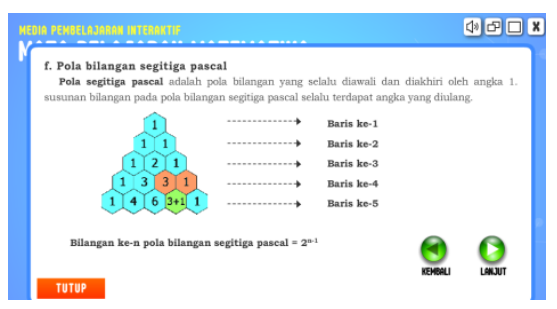

\section{Gambar 4.9 Tampilan Menu Materi Pola Bilangan Segitiga Pascal}

Tampilan menu pola bilangan berikutnya dalah menu pola bilangan segitiga pascal seperti gambar diatas ada penjelasan dan rumus untuk menyelesaikan soal pola bilangan segitiga pascal.

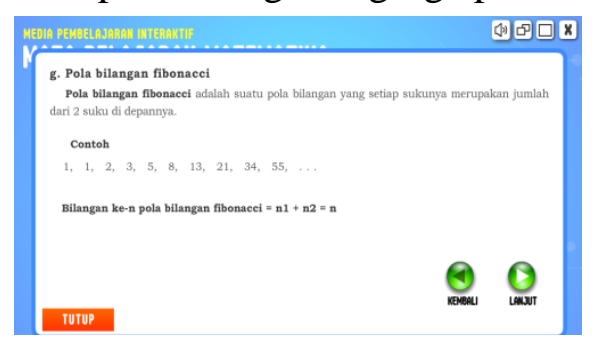

\section{Gambar 4.10 Tampilan Menu Materi Pola Bilangan Fibonacci}

Gambar 4.10 diatas adalah tampilan menu materi pola bilangan fibonacci berupa penjelasan singkat dan rumusnya.

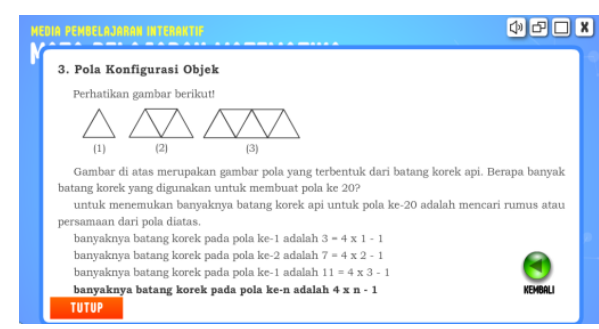

Gambar 4.11 Tampilan Menu Materi Pola Bilangan Konfigurasi Objek

Pola bilangan yang terakhir adalah pola bilangan konfigurasi objek seperti pada gambar diatas, terdapat penjelasan dan rumus cara menyelesaikannya.

\section{d. Validasi Desain}

Media pembelajaran yang sudah dibuat kemudian divalidasi oleh validator yang bertujuan untuk mengetahui apakah media pembelajaran layak digunakan sebagai media pembelajaran atau tidak. Pada validitas yang dilakukan oleh validator terdapat hal yang perlu dirubah atau ditambahkan maka dilakukan revisi desain, setelah validitas dilakukan maka diketahui bahwa media pembelajaran valid atau dapat digunakan dalam pembelajaran. 


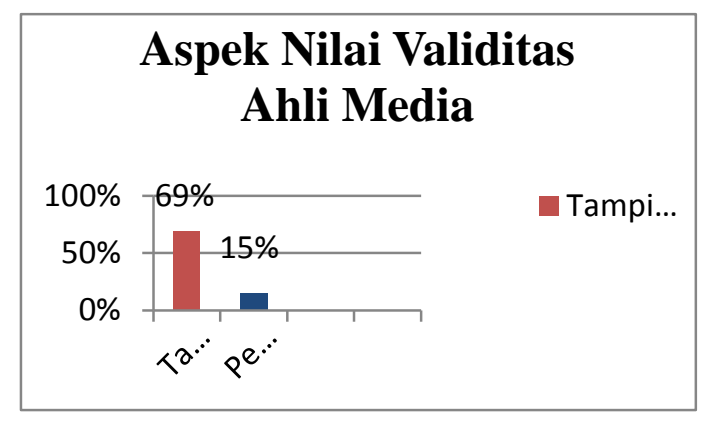

\section{Gambar 4.18 Diagram Aspek Nilai Validasi Ahli Media}

Diagram 4.18 diatas dapat diketahui bahwa media pembelajaran mendapatkan nilai rata-rata pada aspek tampilan $69 \%$ dan aspek pemprograman $15 \%$. Setelah dijumlahkan mendapat nilai rata-rata sebesar 84\% dengan kriteria "Sangat Valid". Dari persentase nilai validasi ahli media maka media pembelajaran layak dan dapat digunakan pada pembelajaran.

$29,3 \%$ aspek pembelajaran $28 \%$ dan aspek kebahasan $26,7 \%$ dengan rata-rata persentase dari ketiga aspek tersebut sebesar 84\% dengan kriteria "Sangat Valid". Artinya media pembelajaran dapat diujicobakan pada siswa disekolah.

\section{e. Revisi Desain}

Saran atau komentar mengenai media pembelajaran matematika berbasis adobe flash pada materi pola bilangan siswa kelas VIII E MTs Al-Khairiyah Pipitan dilihat dari perolehan hasil validasi para ahli kemudian adanya saran untuk perbaikan guna kesempurnaan produk maka dilakukanlah revisi desain.

\section{f. Ujicoba Produk}

Produk yang telah terlewati tahapan validasi dan selesai diperbaiki, kemudian peneliti dapat menguji kelayakan produk dengan melakukan uji coba. Uji coba ini dilakukan dengan memberikan angket kepada pesertadidik dan guru matematika di MTs Al-Khairiyah Pipitan. Uji coba produk tersebut yaitu, dilakukan pada siswa kelas VIII E MTs Al-Khairiyah Pipitan

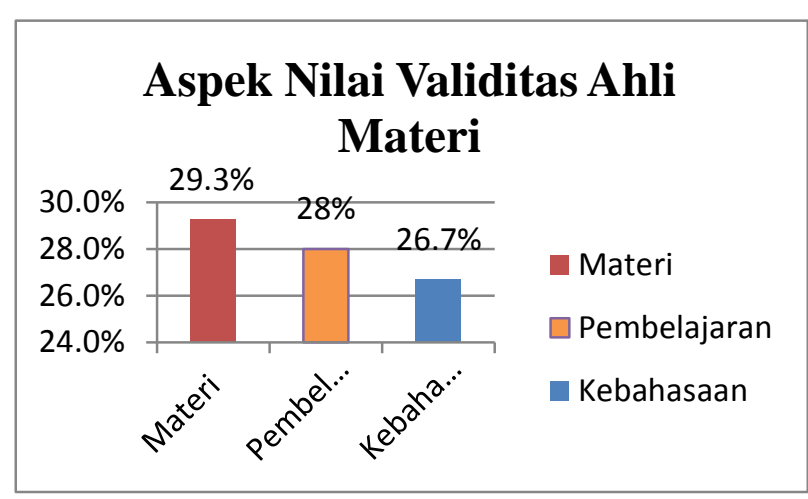

\section{Gambar 4.19 Diagram Aspek Nilai Validasi Ahli Materi}

Dari diagram 4.19 tersebut dapat dietahui bahwa materi pola bilangan dengan menggunakan aplikasi adobe flash dapat digunakan pada pembelajaran dikelas karena hasil uji validasi materi pada validator dengan perolehan hasil persentase pada aspek materi sebesar

dengan jumlah 30 peserta didik dan guru matematika berjumlah 2 orang. Tujuannya untuk mengetahui respon peserta didik dan guru terhadap kelayakan media pembelajaran matematika berbasis adobe flash pada materi pola bilangan. Hasil uji coba respon siswa dan guru dapat membuktikan kelayakan media, agar bisa digunakan pada pembelajaran. Dibawah ini adalah hasil responden siswa dan guru matematika.

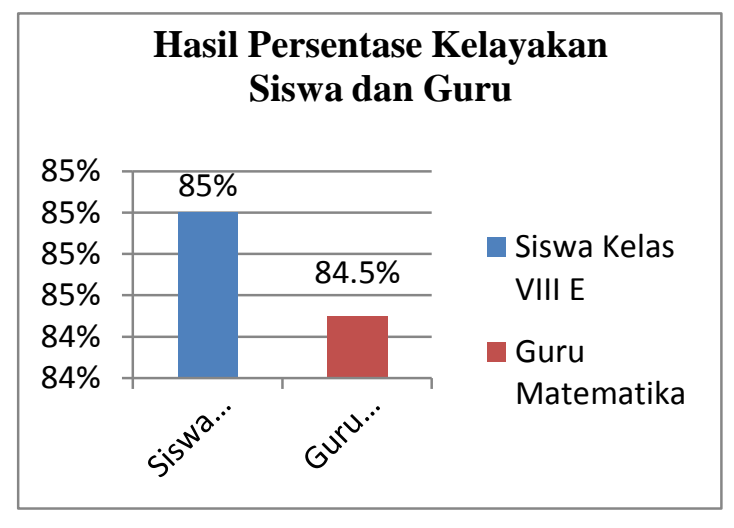

\section{Gambar 4.20 Hasil Persentase Kelayakan Siswa dan Guru}


Dari gambar 4.20 diagram diatas dapat diketahui bahwa materi pola bilangan yang dikemas menggunakan media pembelajaran adobe flash mendapat respon baik dari siswa dan guru matematika di MTs Al-Khairiyah Pipiptan, sehingga dapat dikatakan media pembelajaran berbasis adobe flash layak digunakan dalam pembelajaran matematika.

\section{Pembahasan Penelitian}

Pada penelitian pengembangan ini menguraikan tentang kesesuaian produk akhir dengan tujuan penelitian, hasil validasi yaitu ahli media, ahli materidan ujicobaprodukkepadasiswadan guru Matematika. Untuk menghasilkan produk yang dikembangkan maka peneliti menerapkan prosedur penelitian yang dikembangkan oleh Sugiono, berupa enam langkah yang disesuaikan dengan kebutuhan peneliti dan kondisi saat ini. Langkah yang pertama yaitu potensi dan masalah, pengumpulan data, desain produk, validasi desain, revisi desain, dan uji coba produk.

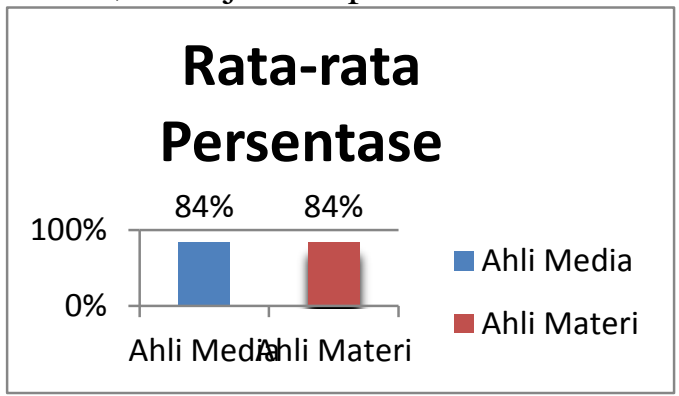

\section{Gambar 4.21 Hasil Penilaian Validasi Para Ahli}

Berdasarkan pada gambar 4.21 diketahui bahwa hasil rata-rata nilai dari ahli media dan ahli materi yaitu sama $84 \%$ dengan kriteria "Sangat Valid" sehingga produk yang dikembangkan dikatakan layak dan dapat diujicobakan pada siswa kelas VIII MTs Al-Khairiyah Pipitan.

\section{Gambar 4.22 Hasil Penilaian Respon Guru dan Siswa}

Seperti gambar 4.22 diatas adapun hasil uji coba terkait respon siswa memperoleh nilai rata-rata $85 \%$ dengan katagori "Sangat Layak" dan nilai rata-rata dari respon guru sebesar 84,5\% dengan katagori sama yaitu "Sangat Layak". Dapat disimpulkan bahwa pengembangan media pembelajaran matematika berbasais adobe flash pada materi pola bilangan layak digunakan pada pembelajaran matematika disekolah.

\section{Simpulan}

Berdasarkan penelitian pengembangan media pembelajaran matematika berbasis adobe flash padamateripolabilanganyang dikembangkan peneliti ternyata layak digunakan. Terbukti dari produk media pembelajaran matematika berbasis adobe flash yang diujicobakan kepada Siswa kelas VIII E dan Guru matematika di MTs Al-Khairiyah Pipitan. Dengan hasil angket respon Siswa sebesar $85 \%$ dan hasil angket respon Guru sebesar $84,5 \%$ dengan kriteria "Sangat Layak" artinya pengembangan media pembelajaran matematika berbasis adobe flash pada materi pola bilangan layak digunakan. Sehingga dapat disimpulkan media pembelajaran matematika berbasis adobe flash layak sebagai media pembelajaran matematika pada materi pola bilangan siswa kelas VIII MTs Al-Khairiyah Pipitan.

\section{Saran}


Bagi penelitian selanjutnya Diharapkan peneliti selanjutnya dapat mengembangkan penelitian pengembangan media pembelajaran matematika berbasis adobe flash pada materi pola bilangan atau materi yang lainnya dengan memperkaya fiturfitur, tampilan, dan sajian pembelajaran didalamnya.

Bagi siswa Pengembangan media pembelajaran matematika berbasis adobe flash pada materi pola bilangan diharapkan dapat menambah motivasi dan

\section{DAFTARPUSTAKA}

Alhusna, Cori.dkk.(2020).Menemukan Pola Perkalian dengan angka9.Jurnal Pendidikan dan Pembelajaran Terpadu

Anwar, Sholikhul.(2020).Pengembangan Media Pembelajaran Matematika Berbasis Adobe Flash pada Materi Sifat-sifat Bangun Ruang.Jurnal Pendidikan Matematika (Kudus)

Anwar, Sholikhul.(2019).Pengembangan Media Pembelajaran Matematika Berbasis Sifat-sifat Bangun Ruang Bagi Siswa Kelas V MI. Skripsi

Ariyanti, S, N, dkk.(2014).Analisis Kesulitan Siswa SMP Kelas VIII dalam Menyelasaikan Soal Pola Bilangan Beradasarkan Kemampuan Penalaran Matematika.Jurnal On Education

Arriza, L.(2020).Pengembangan Media Pembelajaran Matematika Berbasis Adobe Flash Pada Materi Lingkaran untuk Kelas VIII SMP Swasta Islam Annur Prima.Skripsi

As'ari,A,R,dkk.(2019).Matematika.Depo $\mathrm{k}$ : CV Arya Duta

Auliya, Nanang N, F.(2018). Pengembangan Pembelajaran Berbasis Multimedia Interaktif Menggunakan minatbelajar siswa pada mata pelajaran matematika.

Bagi Guru, agar dapat memanfaatkan teknologi yang berhubungan dengan media pembelajaran matematika, seperti software adobe flash.

Bagi Sekolah, diharapkan Pengembangan media pembelajaran matematika berbasis adobe flash pada materi pola bilangan dapat sebagai masukan dalam menyusun program peningkatan kualitas sekolah.

Adobe Flash CS6 dalam Pembelajaran Matematika Pada Kelas X Materi Pokok Pertidaksamaan Satu Variabel.Jurnal Pendidikan Matematika

Azhar,Arsyad.(2020).MediaPembelajara $n$. Depok : PT. RajaGrafindo Persada

Cahyanindya,B,A, dkk. (2020). Pengembangan Media Puppy Berbasis Adobe Flash Cs6 Untuk Pembelajaran Teorema Pythagoras. Jurnal Pendidikan Matematika

Dharmalau,Andy.dkk.(2021).Perancanga $n$ Media Pembelajaran Lagu Daerah AnimasiInteraktif Menggunakan Adobe Flash.Jurnal Elektro \& Informatika

Ernawati, Iis.ddk.(2016).Uji Kelayakan Media Pembelajaran Interaktif Pada Mata Pelajaran Administrasi Server.Electronis Informatics and Vocational Education

Hendriana, Heris.dkk.(2014).Penilaian Pembelajaran Matematika.Bandung:PT Refika Aditama

Hidayah,Sofiyatul,dkk.(2017).Pengguna an Media Pembelajaran Interaktif Dengan Aplikasi adobe Flash CS6 
14 Fatmawati, Novia Ratna Sari, Nurul Awaliyati Dewi, Pengembangan Media Pembelajaran Matematika Berbasis Adobe Flash Pada Materi Pola Bilangan

Untuk Meningkatkan Motivasi Belajar Pada Kompetensi Dasar Menganalisis Peran, Fungsi, dan Manfaat Pajak.Jurnal Pendidikan Ekonomi

Hidayatullah,Muhammad.(2017).Pengem bangan Media Pembelajaran Menggunakan Software Adaobe Flash pada Pokok Bahasan Barisan dan Deret Kelas XII SMA Negeri 16 Makassar.Skripsi

Hidayah,Sofiyatul,dkk.(2017).Pengguna an Media Pembelajaran Interaktif dengan Aplikasi Adobe Flash CS6 Untuk Meningkatkan Motivasi Belajar Pada Kompetensi Dasar Menganalisis Peran, Fungsi, dan Manfaat Pajak. Jurnal Pendidikan Ekonomi

Khairunnisa,Fitri,dkk.(2020).Mengemban gkan Kemampuan Penalaran Induktif dengan Model-Eliciting Activities pada Pembelajaran RemedialPola Bilangan untukKelas VIII ESMP Negeri 22 Jakarta.JRPMS (Jurnal Riset Pembelajaran Matematika Sekolah)

Lestari, K, E.dkk.(2017).Penelitian Pendidikan Matematika.Bandung : PT Refika Aditama

Nasihin, Khairun.(2019).Pengembangan Media Pembelajaran Berbasis Adobe Flash CS6 Materi Fotosintesis Kelas VII MTs Muslimat NU Palangka Raya.Skripsi

Nurmawanti, Iva, dkk.(2020).Strategi Kontruktif dan Dekonstruktif Proses Identifikasi Pola Bilangan Mahasiswa Calon Guru.Jurnal Derivat.
Pemerintah Republik Indonesia Nomor 74 Tahun 2008 Tentang Guru Pasal 3 Ayat 2

Prasetyo,Giri, dkk.(2016).Pengembangan Adobe Flash Pada Pembelajran Tematik-Integratif Berbasis Scientific Approach Subtema Indahnya Peninggalan Sejarah.Jurnal Prima Edukasia

Raharjo, Sigit, dkk.(2020)Analisis Kemampuan Penalaran Aljabar Siswa SMP dalam Pemecahan Masalah Pola Bilangan.Jurnal Ilmiah Pendidikan Matematika

Resiana,Wijaya.(2017).Modul

Pengayaan Matematika.CV Media Adi Karya Grafika

Rezeki, Sri.(2018).Pemanfaatan Adobe Flash CS6 Berbasis Problem Base Learning Pada Materi Fungsi Komposisi dan Fungsi Invers.Jurnal Pendidikan Tambusai

Sa'adah, N, R.(2020).Metode Penelitian $R$ \& D.Bandung : Literasi Nusantara

Sari, C, P, dkk.(2019).Analisis Berpikir Aljabar Siswa Pada Materi Pola Bilangan.Seminar Nasional Matematika Dan Pendidikan Matematika

Sari,Rizki,S,P,dkk.(2018).Pengembanga $n$ Bahan ajar Matematika pada Materi bangun ruang sisi datar Menggunakan Softawre Adobe Flash untuk kelas VIII SMP.Seminar Nasional Matematika dan Pendidikan Matematika 
Sari, T, K.(2019). Pengembangan Media Pembelajaran Matematika Berbasis Adobe Flash di SD Negeri Metro Barat.Skripsi

Setia, M, O,dkk.(2018).Pengembangan Media Pembelajaran dengan Menggunakan Adobe Flash CS6 pada Materi Hukum Newton Tentang Gerak Dan Penerapannya.Jurnal Pendidikan Fisika

Setiawan, E, Y.(2020). Analisis Kesalahan Siswa dalam Menggeneralisasi Pola Linear.Jurnal nasional Pendidikan Matematika.

Wijaya,Resiana.(2017).Modul Pengayaan Matematika. CV: Media Adi Grafika
Sugandi,K,M,dkk.(2019).Pengembangan Multimedia Adobe Flash Pembelajaran Biologi Melalui Project Based Learning Untuk Meningatkan Kreativitas Siswa Pada Konsep Ekosistem.Jurnal Ilmiah Pendidikan Biologi

Sugiono.(2015).MetodePenelitianKuantit atif Kualitati dan $R \& D$. Bandung : Alfabeta

Widada, dkk.(2019).Cara Mudah Membuat Media Pembelajaran Menggunakan Adobe Flash Professional CS6.Yogyakarta: Gava Media

Yaumi, Muhammad.(2018).Media dan Teknologi Pembelajaran : Prenamedia Group 